\title{
Probiotic supplementation during pregnancy or infancy for the prevention of asthma and wheeze: systematic review and meta-analysis
}

\begin{abstract}
Objective To evaluate the association of probiotic supplementation during pregnancy or infancy with childhood asthma and wheeze.

Design Systematic review and meta-analysis of randomised controlled trials.

Data sources Medline, Embase, and Central (Cochrane Library) databases from inception to August 2013, plus the World Health Organization's international clinical trials registry platform and relevant conference proceedings for the preceding five years. Included trials and relevant reviews were forward searched in Web of Science.

Review methods Two reviewers independently identified randomised controlled trials evaluating probiotics administered to mothers during pregnancy or to infants during the first year of life. The primary outcome was doctor diagnosed asthma; secondary outcomes included wheeze and lower respiratory tract infection.

Results We identified 20 eligible trials including 4866 children. Trials were heterogeneous in the type and duration of probiotic

supplementation, and duration of follow-up. Only five trials conducted follow-up beyond participants' age of 6 years (median 24 months), and none were powered to detect asthma as the primary outcome. The overall rate of doctor diagnosed asthma was $10.7 \%$; overall rates of incident wheeze and lower respiratory tract infection were $33.3 \%$ and $13.9 \%$, respectively. Among 3257 infants enrolled in nine trials contributing asthma data, the risk ratio of doctor diagnosed asthma in
\end{abstract}

participants randomised to receive probiotics was 0.99 (95\% confidence interval 0.81 to $1.21, I^{2}=0 \%$ ). The risk ratio of incident wheeze was 0.97 ( 0.87 to $1.09, I^{2}=0 \%, 9$ trials, 1949 infants). Among 1364 infants enrolled in six trials, the risk ratio of lower respiratory tract infection after probiotic supplementation was 1.26 (0.99 to $1.61, I^{2}=0 \%$ ). We adjudicated most trials to be of high (ten trials) or unclear (nine trials) risk of bias, mainly due to attrition.

Conclusions We found no evidence to support a protective association between perinatal use of probiotics and doctor diagnosed asthma or childhood wheeze. Randomised controlled trials to date have not yielded sufficient evidence to recommend probiotics for the primary prevention of these disorders. Extended follow-up of existing trials, along with further clinical and basic research, are needed to accurately define the role of probiotics in the prevention of childhood asthma.

Systematic review registration PROSPERO (CRD42013004385).

\section{Introduction}

Over the past half century, there has been a sharp rise in the global prevalence of asthma, particularly in children. ${ }^{1}$ About 300 million people worldwide are estimated to have asthma, and the prevalence has been increasing by $50 \%$ every decade. ${ }^{1}$ As the most common chronic disease of childhood, asthma affects roughly one in five children in the United Kingdom and United States, ${ }^{2}$ and is the leading cause of school absenteeism. ${ }^{3}$ 
The total annual cost of asthma to society has been estimated at $€ 19$ bn (£16.2bn; \$26.2bn) in Europe ${ }^{4}$ and \$56bn in the US. ${ }^{5}$ Recurrent wheeze frequently precedes the diagnosis of asthma, and is estimated to occur in more than $20 \%$ of infants. ${ }^{67}$

The microflora hypothesis of allergic disease has been proposed to explain the rising incidence of asthma and other allergic disorders. ${ }^{8}$ Commensal gut bacteria stimulate development of the neonatal immune system; therefore, disruption of the gut microbiota during early life may contribute to immune disorders later in childhood. ${ }^{9}$ Indeed, prospective studies have shown that perturbation of the infant gut microbiota precedes development of atopic dermatitis (allergic eczema), ${ }^{10-12}$ which is widely regarded as the first step in the progressive "atopic march" towards allergic rhinitis and asthma. ${ }^{13}$ Moreover, early life factors that disrupt the gut microbiota (such as caesarean delivery, lack of breastfeeding, and use of antibiotics) increase the risk of asthma. ${ }^{14-16}$

In the light of this evidence, probiotics-live micro-organisms that, when administered in adequate amounts, confer a health benefit on the host - have been proposed for the prevention and treatment of allergic disorders including asthma. ${ }^{17}{ }^{18}$ Although naturally present in fermented foods, probiotics are increasingly being produced and administered as supplements in preventative and therapeutic medicine. ${ }^{19}$ A recent meta-analysis of 14 randomised controlled trials showed that probiotic supplementation during pregnancy or infancy decreased the incidence of atopic dermatitis by $21 \%{ }^{20}$ Less clinical evidence exists for probiotics in the prevention of wheeze or asthma, ${ }^{21}$ but animal studies have shown that perinatal use of probiotics can prevent airway inflammation and hyper-reactivity. ${ }^{22}{ }^{23} \mathrm{~A}$ 2007 Cochrane review of early life probiotics for prevention of allergic diseases reported no benefit for asthma prevention after probiotic supplementation, ${ }^{24}$ based on findings from three trials ${ }^{25-27}$ enrolling a total of 617 infants. All three existing trials have since published extended follow-up results, ${ }^{28-31}$ and six additional trials enrolling 2308 infants have published new findings on probiotics for asthma prevention. ${ }^{21}{ }^{32-36}$ Prevention of related outcomes (wheeze or lower respiratory infection) was not covered in the 2007 Cochrane review.

The purpose of this systematic review was to identify, critically appraise, and meta-analyse data from prospective randomised trials evaluating the use of probiotic supplements for the primary prevention of asthma or childhood wheeze.

\section{Methods}

Using an a priori published protocol, ${ }^{37}$ we conducted our systematic review using methodological approaches outlined in the Cochrane Handbook for Systematic Reviewers ${ }^{38}$ and reported according to the criteria of preferred reporting items for systematic reviews and meta-analyses (PRISMA). ${ }^{39} \mathrm{~A}$ technical panel of experts from multiple fields (nutrition, paediatric asthma, research methodology) formulated the review questions, reviewed the search strategies and review methods, and provided input throughout the review process.

\section{Populations, interventions, comparators, outcome measures, settings, and study designs}

We included only randomised controlled trials of pregnant women or healthy infants under 1 year of age (web appendix, table S1). Our primary research question was "In healthy infants under 1 year of age, are probiotics (administered prenatally or postnatally) safe and protective against the development of wheeze or asthma, compared to placebo, or to no intervention?"
The main outcome measure was doctor diagnosed asthma. Secondary outcomes included wheeze (incident or recurrent), asthma drug use, hospital admission for asthma, and the asthma predictive index score. ${ }^{40}$ Lower respiratory tract infections were also included as a secondary outcome because these infections generally involve wheeze and could predispose for asthma. ${ }^{41}$ Safety outcomes included gastrointestinal disturbances, allergic reaction to probiotics, and withdrawal due to perceived side effects. Table S2 presents inclusion and exclusion criteria (web appendix).

\section{Search strategy for identification of studies}

We searched Medline, Embase, and Central (Cochrane Library) databases from inception to August 2013 for relevant citations of published trials, using individualised search strategies for each database. Table S3 presents the Medline strategy (web appendix). We searched the World Health Organization's international clinical trials registry platform and relevant conference proceedings for the preceding five years to identify relevant planned, ongoing, or recently completed but unpublished trials (American Thoracic Society; American Academy of Allergy, Asthma, and Immunology; European Respiratory Society; European Academy of Allergy and Clinical Immunology; and the American Association for Parenteral and Enteral Nutrition). We performed forward searches of included trials and relevant reviews in the Web of Science to identify additional citations, and contacted study authors to request relevant unpublished data. Reference lists of narrative and systematic reviews and of the included trials were searched for additional citations. We performed reference management in EndNote X6 (Thomson Reuters).

\section{Study selection}

We used a two stage process for study screening and selection using standardised and piloted screening forms. Firstly, two reviewers (MBA and JGC) independently screened the titles and abstracts of search results to determine whether each citation met the inclusion criteria. Second, the full text versions of potentially relevant citations were reviewed independently with reference to the predetermined inclusion and exclusion criteria (web appendix, table S2). Discrepancies between the two reviewers were resolved through consensus by discussion with a third reviewer (AMA-S), as required.

\section{Data abstraction and management}

Two reviewers (MBA and JGC) independently extracted data from included trials, using standardised and piloted data extraction forms. Discrepancies between the two reviewers were resolved through consensus in discussion with a third reviewer (AMA-S), as required. Extracted data included funding sources, demographics of the enrolled mothers and infants (family history of allergic disease, mode of delivery, infant sex, gestational age or age at enrolment, and breastfeeding), details of probiotic intervention (organism, daily dose, timing, duration, and method of administration), and relevant outcomes as described above. Since the nature of asthma and wheeze can change over time, ${ }^{42}$ outcome data were extracted for predefined time periods (age $<3$ years, 3 to $<6$ years, and $\geq 6$ years). When a trial reported results for more than one time period, results from the longest follow-up were included in the main meta-analysis; results from earlier time periods were included in subgroup analyses. Data management was performed using Microsoft Excel 2007. 


\section{Assessment of methodological quality and potential risk of bias}

We evaluated internal validity using the Cochrane Collaboration's risk of bias tool, ${ }^{43}$ which assesses randomisation and allocation of participants; blinding of participants, personnel, and outcome assessors; incomplete or selective reporting; and other relevant sources of bias. If trial methodology was unclear from the published report, authors were contacted for clarification.

\section{Measures of treatment effect}

We analysed data from the included trials using Review Manager (RevMan 5.2, the Cochrane Collaboration). ${ }^{44} \mathrm{~A}$ formal meta-analysis was conducted if the data were statistically and clinically homogeneous. Pooled dichotomous data were expressed as a risk ratio, or Peto odds ratio in the event of rare outcomes. ${ }^{45}$ A risk ratio or odds ratio less than one suggests a lower rate of the outcome (for example, asthma) among participants randomised to receive probiotics than among the control group. We used the random effects model for all analyses, with the exception of the Peto odds ratio (fixed effect model). Statistical heterogeneity was explored and quantified using the $\mathrm{I}^{2}$ statistic. ${ }^{46}$ All tests of statistical inference reflect a two sided $\alpha$ value of 0.05 .

\section{Subgroup analyses and meta-regression}

We performed subgroup analyses to determine summary effect estimates in several prespecified groups, including: the participant receiving the intervention (mother or infant), duration and timing of intervention (prenatal or postnatal), probiotic organism and dose, duration of follow-up or age at assessment, asthma risk, caesarean delivery rate, geographical area, and source of funding. ${ }^{37} \mathrm{We}$ conducted meta-regression to evaluate differences in effect according to duration of follow-up as a continuous variable, using Comprehensive Meta Analysis (Biostat). ${ }^{47}$

\section{Results}

\section{Trial characteristics and study populations}

Of 3011 citations identified from electronic and hand searches, we included 20 unique randomised trials enrolling a total of 4866 infants (fig $1 \Downarrow$, table $1 \Downarrow$ ). These trials were represented by 20 primary articles, ${ }^{21-58}$ four companion articles, ${ }^{59-62} 10$ extended follow-up publications ${ }^{28-31}$ 63-68 plus one forthcoming report, and eight duplicate conference abstracts. ${ }^{69-76}$ All were double blind, placebo controlled trials published in peer reviewed journals between 2001 and 2013. Sixteen trials were conducted in Europe, while four trials were conducted in Australia, ${ }^{27}{ }^{49}$ New Zealand, ${ }^{36}$ and Taiwan. ${ }^{34}$ Based on family history or existing allergic disease in the mother or infant (definitions provided in web appendix, table S4), 14 of 20 trials enrolled participants at high risk for asthma; the remaining six trials $^{21-57}$ were conducted in unselected populations. The caesarean delivery rate in study populations ranged from $0 \%$ to $45 \%$, and was not reported in six trials. ${ }^{21-52}$ Most trials (14 of 20) did not restrict infant feeding practices, although six trials ${ }^{50-58}$ required exclusive formula feeding for enrolment. Nearly all trials (19 of 20) reported some degree of industry support (funding, salary support, or supplied products), including seven trials involving authors employed by the industry sponsor. ${ }^{32-58}$ Overall, most trials were adjudicated to be of unclear (nine of 20 ) or high risk of bias (10 of 20); only one trial ${ }^{55}$ was considered to have a low risk of bias across all domains (web appendix, table S5; fig S1). Of 20 trials, most had adequate random sequence generation $(n=18)$, allocation concealment $(n=18)$, and blinding of outcome assessment $(n=18)$. However, eight and nine trials were subject to unclear and high risk of attrition bias, respectively, owing to incomplete outcome data after substantial loss to follow-up. Three trials were at high risk of performance bias due to unblinding of study participants at extended follow-up assessments (including one trial with unpublished data). ${ }^{28} 68$

\section{Probiotic interventions}

Table $2 \Downarrow$ presents details of the probiotic interventions administered in each trial. All trials evaluated probiotic supplements, rather than consumer food products. Supplements were delivered orally by various methods, including capsules; oil droplets; and suspensions in water, milk, or infant formula. One trial ${ }^{49}$ exclusively evaluated prenatal maternal supplementation, 10 exclusively evaluated postnatal infant supplementation, while nine evaluated a combination of prenatal and postnatal supplementation. The total duration of intervention ranged from one to 25 months (median 6.3 months). Various probiotic organisms were tested in isolation or in combination, including four Bifidobacterium species (B bifidum, B longum, two strains of $B$ breve, and four strains of $B$ lactis), and six Lactobacillus species (Lacidophilus, L casei, L lactis, L reuteri, two strains of $L$ paracasei, and three strains of $L$ rhamnosus). Six trials ${ }^{21-54}$ evaluated combinations of multiple probiotic organisms, and five $\mathrm{e}^{32-58}$ evaluated probiotics in combination with prebiotics (selectively fermented compounds that facilitate changes in the composition or activity of the gut microbiota to confer benefits on host health). ${ }^{77}$ The daily dose of probiotics ranged from $10^{8}$ to $10^{11}$ colony forming units, and was not quantifiable in six trials using supplemented infant formulas that were fed without restraint. ${ }^{50-58}$ Compliance was assessed by a variety of methods, including maternal interview or daily diaries, counting of unused supplements, and faecal analysis.

\section{Outcomes}

Among the included trials, the duration of follow-up ranged from four months to eight years, and the median age at final assessment was 24 months (table 1). Nine trials reported clinical asthma diagnosis, 11 reported wheezing outcomes, and six reported lower respiratory tract infections; table S6 provides individual study definitions for these outcomes (web appendix). One trial reported the asthma predictive index score, ${ }^{49}$ two reported asthma drug use, ${ }^{54} 58$ and none reported admission to hospital for asthma. Adverse events were inconsistently reported.

\section{Primary outcome: asthma}

Nine trials including 3257 children contributed asthma data for meta-analysis (fig $2 \Downarrow$ ). Incidence of doctor diagnosed asthma at final assessment was $11.2 \%$ among patients randomised to receive probiotics and $10.2 \%$ among those receiving placebo (risk ratio $0.99,95 \%$ confidence interval 0.81 to $1.21, \mathrm{I}^{2}=0 \%$ ). Results were similar when expressed as a Peto odds ratio for rare events.

\section{Secondary outcomes: wheeze, lower respiratory tract infection, and adverse events}

Nine trials including 1949 children contributed incident wheeze data for meta-analysis (fig $3 \Downarrow$ ). Incident wheeze at final assessment was similar after supplementation with probiotics or placebo $(35.0 \% \vee 31.1 \%$; risk ratio $0.97,95 \%$ confidence interval 0.87 to $1.09, \mathrm{I}^{2}=0 \%$ ). Three trials reported recurrent 
wheezing, and meta-analysis was not pursued owing to considerable statistical heterogeneity $\left(\mathrm{I}^{2}=83 \%\right)$. Two of these trials $^{295}$ reported an increased risk of recurrent wheeze after probiotic supplementation, whereas the third trial ${ }^{58}$ reported a decreased risk (web appendix, fig S2).

Six trials including 1364 children contributed data on lower respiratory tract infections. The incidence of lower respiratory tract infection was $14.5 \%$ among children randomised to receive probiotics, and $13.2 \%$ among those who received placebo (risk ratio $1.26,95 \%$ confidence interval 0.99 to $1.61, \mathrm{I}^{2}=0 \%$ ).

Notably, four of six trials documented lower respiratory tract infections non-systematically as adverse events ${ }^{48-53}$ rather than as primary or secondary outcomes. Excluding these four trials, the pooled risk ratio of lower respiratory tract infection associated with probiotics was 1.11 ( 0.70 to $1.76, \mathrm{I}^{2}=35 \%$; fig $4 \Downarrow)$.

Most trials did not systematically screen for or report the incidence of relevant safety outcomes, including severe gastrointestinal disturbances or allergic reactions (web appendix, table S7). The Peto odds ratio associated with withdrawal due to perceived side effects was 1.45 (95\% confidence interval 0.66 to $3.17, \mathrm{I}^{2}=0 \%$; eight trials, 2732 children; web appendix, fig S3).

\section{Subgroup analysis}

We evaluated the efficacy of probiotics for prevention of asthma in children according to predefined subgroups (table $3 \Downarrow$ ). Subgroup analyses by participant type (mother, infant, or both), timing of intervention (prenatal, postnatal, or both), or duration of intervention ( $\leq 6$ or $>6$ months) did not show significant differences. However, individual subgroups were subject to type II errors, owing to small sample sizes. Similarly, we observed no statistical differences according to baseline asthma risk, probiotic dose or organism, caesarean delivery rate, feeding restrictions, geographical area, risk of bias, or industry authorship. Differences were not observed according to duration of follow-up, whether classified according to predefined strata (table 3) or assessed as a continuous variable by meta-regression (web appendix, fig S4). We found no significant differences across subgroups for incident wheeze (table 3); subgroup analyses were not pursued for recurrent wheeze or lower respiratory tract infection because of the small number of trials reporting these outcomes.

\section{Discussion}

In this systematic review and meta-analysis of randomised controlled trials, we found no evidence to support a protective association between probiotic supplementation during pregnancy or early life, and subsequent development of childhood asthma or wheeze. Although inadequately reported, probiotic supplementation could be associated with clinically relevant increases in lower respiratory tract infections.

\section{Comparison of results with other studies}

Our review provides a timely update to the 2007 Cochrane review of probiotics for prevention of allergic diseases. ${ }^{24}$ The Cochrane review reported no benefit for the prevention of asthma after probiotic supplementation, based on findings from three trials enrolling a total of 617 infants. ${ }^{25-27}$ Our review evaluates updated long term findings from these three original trials, ${ }^{28-31}$ and adds results from six new trials (2308 infants) reporting on probiotics for asthma prevention. ${ }^{21-36}$ Furthermore, we have evaluated 11 additional probiotic trials (1976 infants) reporting asthma related outcomes (wheeze or lower respiratory infection) that were not analysed in the 2007 Cochrane review. After systematic evaluation of these new and extended trial results, involving over 4000 additional children, we conclude that there is still insufficient evidence to recommend probiotics for the primary prevention of asthma. Our findings further identify several unanswered questions and highlight opportunities for future research.

\section{Opportunities for future research}

Despite widespread enthusiasm for evaluating probiotics to prevent allergic disease ${ }^{17}$ and recognition of asthma as a major allergic disease in childhood, ${ }^{178}$ relatively few randomised trials have formally tested the use of probiotics for asthma prevention. Only nine probiotic trials have reported asthma diagnosis, and none were powered for asthma detection as the primary outcome. Long term follow-up is essential for asthma prevention studies because diagnosis is challenging before age 6 years. ${ }^{79} 80$ However, among the 20 trials included in our review, the median age at last follow-up was 24 months, and only five trials reported outcomes at or beyond 6 years of age (including one trial with unpublished data). ${ }^{28-68}$ Moreover, long term follow-up was frequently subject to high or unclear risk of bias owing to attrition or the unblinding of participants. Extended follow-up data from other established trials are highly anticipated, including planned adolescent assessments by Kalliomaki ${ }^{26}$ and Kukkone $^{32}$ and colleagues. Because of the paucity of long term follow-up data among probiotic trials, we also evaluated wheeze as an early presentation of asthma. However, only a minority of wheezing infants will ultimately develop asthma later in childhood. $^{81}$

Thus, extended follow-up of existing studies, combined with novel, respiratory focused trials, ${ }^{82-84}$ will be necessary to define the role of probiotics for asthma prevention. Owing to the dynamic nature of the gut microbiota, trials evaluating prolonged probiotic supplementation (beyond the first year of life) may also be needed. As West and colleagues have shown, ${ }^{67}$ probiotics are transient colonisers of the intestine, indicating that prolonged supplementation may be required to achieve durable benefit.

Our findings also highlight a need to further consider the effect of probiotics on the incidence and severity of recurrent wheeze and lower respiratory tract infections. Recurrent wheeze during infancy is considered a better predictor of asthma than incident wheeze, ${ }^{40}$ yet only three of 10 trials documenting wheeze reported variable measures of recurrence, ${ }^{27-58}$ and statistical heterogeneity precluded meta-analysis. Reporting of lower respiratory tract infections was similarly incomplete and variably defined. In six trials reporting this outcome, we observed a trend toward increased infections in children who received probiotics. Future trials should systematically define and capture recurrent wheeze, along with lower respiratory tract infections and other relevant safety outcomes.

Our subgroup analyses indicated that the effect of probiotics was similar regardless of the timing of intervention (prenatal $v$ postnatal $v$ both) or the participant receiving the intervention (mother $v$ infant $v$ both). The efficacy of specific probiotic organisms was difficult to assess because of the large variety of strains, combinations, and doses tested, and requires further investigation. Different probiotic organisms probably have distinct effects on the gut microbiota and host physiology. A recent animal study found that four Lactobacillus species had markedly different immunomodulatory effects, ${ }^{85}$ and at least one clinical study has shown strain specific anti-allergic effects. ${ }^{36}$ Further basic and clinical research is also needed to characterise 
the mechanisms by which probiotics influence asthma development, including how specific organisms colonise the gut, modify the resident microbiota, and ultimately affect host immunity and health. Such knowledge will help optimise the selection of probiotic organisms and the design of intervention regimens for future study.

Finally, identifying infant populations most likely to benefit from probiotics is highly desirable. For example, one trial has shown that probiotics were protective against $\operatorname{IgE}$ associated allergic disease in infants delivered by caesarean section (whose gut microbiota is disrupted ${ }^{86}$ ), but not in their vaginally delivered counterparts. ${ }^{64}$ With trial level data, we could not identify differential efficacy according to caesarean delivery rate, but this and other microbiota disrupting exposures (such as formula feeding and antibiotic treatment) warrant further study as possible indications for probiotic supplementation in the prevention of asthma and wheeze.

\section{Strengths and weaknesses of the study}

The strengths of this review included the completeness of the search strategy, which reviewed multiple citation databases, trial registries, and conference proceedings. By omitting outcome related search terms, we identified trials that were not primarily focused on asthma or allergic disease, but nevertheless reported relevant outcomes. ${ }^{50-57} \mathrm{We}$ focused on patient centred outcomes and evaluated efficacy in the context of relevant safety outcomes and adverse events. Finally, we used an a priori published protocol and followed established methodological guidelines in the conduct and reporting of this review. Limitations include pooling data from trials conducted in distinct populations (for example, infants at high risk for asthma, or unselected populations) receiving different probiotic formulations (various organisms with a 1000 times range in daily dose) through varying regimens (prenatal or postnatal supplementation, for 1-25 months). Subgroup analyses were susceptible to type II errors owing to relatively small sample sizes.

\section{Conclusion}

We found no evidence to support a protective association between perinatal administration of probiotics, and doctor diagnosed asthma or childhood wheeze. There is currently insufficient evidence to recommend probiotics for the primary prevention of these disorders, and further research is warranted to explore the potential association between probiotic supplementation and increased risk of lower respiratory tract infection. Extended follow-up of existing trials, along with further clinical and basic research, are needed to accurately define the role of probiotics in the prevention of childhood asthma.

We thank the George and Fay Yee Centre for Healthcare Innovation for infrastructure support, and the following authors for providing unpublished data: G T Rijkers (University College Roosevelt Academy, The Netherlands) D M W Gorissen (University Medical Centre Utrecht, The Netherlands), J Hol (St Elisabeth Hospital, Curacao), P Steenhout (Nestec), K Kukkonen and E Savilahti (Helsinki University Central Hospital, Finland), and K Wickens (University of Otago, New Zealand). Contributors: MBA, AMA-S, and RZ conceived and designed the study with input from $A B B, C J F, C D R$, and ALK. CF provided guidance on search strategies. MBA and JGC screened and reviewed studies, extracted data, and assessed the quality of included trials. MBA analysed the data and all authors contributed to its interpretation. MBA drafted the manuscript and all authors participated in the revision process and have approved this submission for publication. MBA is guarantor, had full access to all of the data in the study, and can take responsibility for the integrity of the data and the accuracy of the data analysis.

Funding: No specific funding was obtained for this study. MBA is a Canadian Institutes of Health Research Banting postdoctoral fellow, and recipient of a Parker B Francis research opportunity award and Alberta Innovates Health Solutions incentive award. RZ is a recipient of a randomised controlled trial mentorship award from the Canadian Institute of Health Research. ALK is the research chair in maternal-child health and the environment at the Women and Children's Health Research Institute. None of the funders influenced the conduct of this research

Competing interests: All authors have completed the ICMJE uniform disclosure form at www.icmje.org/coi_disclosure.pdf and declare: no support from any organisation for the submitted work; no financial relationships with any organisations that might have an interest in the submitted work in the previous three years; no other relationships or activities that could appear to have influenced the submitted work.

Ethical approval: As this study did not involve the collection of new data, but rather the analysis of data from previously published research, no ethics approval was sought.

Data sharing: The RevMan file used to generate summary effect measures will be made available on request.

MBA, as guarantor, affirms that the manuscript is an honest, accurate, and transparent account of the study being reported; that no important aspects of the study have been omitted; and that any discrepancies from the study as planned and registered have been explained.

Braman SS. The global burden of asthma. Chest 2006;130:4-12S.

2 Pearce N, Ait-Khaled N, Beasley R, Mallol J, Keil U, Mitchell E, et al. Worldwide trends in the prevalence of asthma symptoms: phase III of the International Study of Asthma and Allergies in Childhood (ISAAC). Thorax 2007;62:758-66.

3 Harrison BD, Pearson MG. Audit in acute severe asthma-who benefits? J R Coll Physicians Lond 1993;27:387-90.

4 Accordini S, Corsico AG, Braggion M, Gerbase MW, Gislason D, Gulsvik A, et al. The cost of persistent asthma in Europe: an international population-based study in adults. Int Arch Allergy Immunol 2013;160:93-101.

5 Barnett SB, Nurmagambetov TA. Costs of asthma in the United States: 2002-2007. J Allergy Clin Immunol 2011:127:145-52.

6 Mallol J, Garcia-Marcos L, Sole D, Brand P, Group ES. International prevalence of recurrent wheezing during the first year of life: variability, treatment patterns and use of health resources. Thorax 2010;65:1004-9.

7 Ly NP, Gold DR, Weiss ST, Celedon JC. Recurrent wheeze in early childhood and asthma among children at risk for atopy. Pediatrics 2006;117:e1132-8.

8 Shreiner A, Huffnagle GB, Noverr MC. The "microflora hypothesis" of allergic disease. Adv Exp Med Biol 2008;635:113-34.

9 Azad MB, Kozyrskyj AL. Perinatal programming of asthma: the role of gut microbiota. Clin Dev Immunol 2012;2012:932072.

10 Penders J, Stobberingh EE, Thijs C, Adams H, Vink C, van RR, et al. Molecular fingerprinting of the intestinal microbiota of infants in whom atopic eczema was or was not developing. Clin ExpAllergy 2006:36:1602-8.

11 Wang M, Karlsson C, Olsson C, Adlerberth I, Wold AE, Strachan DP, et al. Reduced diversity in the early fecal microbiota of infants with atopic eczema. J Allergy Clin/mmunol 2008;121:129-34

12 Abrahamsson TR, Jakobsson HE, Andersson AF, Bjorksten B, Engstrand L, Jenmalm MC. Low diversity of the gut microbiota in infants with atopic eczema. J Allergy Clin/mmunol 2012;129:434-40.

13 Zheng T, Yu J, Oh MH, Zhu Z. The atopic march: progression from atopic dermatitis to allergic rhinitis and asthma. Allergy Asthma Immunol Res 2011;3:67-73.

14 Thavagnanam S, Fleming J, Bromley A, Shields MD, Cardwell CR. A meta-analysis of the association between caesarean section and childhood asthma. Clin ExpAllergy 2008;38:629-33.

15 Kull I, Melen E, Alm J, Hallberg J, Svartengren M, van Hage M, et al. Breast-feeding in relation to asthma, lung function, and sensitization in young schoolchildren. J Allergy Clin Immunol 2010;125:1013-9.

16 Kozyrskyj AL, Ernst P, Becker AB. Increased risk of childhood asthma from antibiotic use in early life. Chest 2007;131:1753-9.

17 Fiocchi A, Burks W, Bahna SL, Bielory L, Boyle RJ, Cocco R, et al. Clinical use of probiotics in pediatric allergy (CUPPA): a World Allergy Organization position paper. World Allergy Organ J 2012:5:148-67.

18 Ismail IH, Licciardi PV, Tang ML. Probiotic effects in allergic disease. J Paediatr Child Health 2013;49:709-15.

19 Aureli P, Capurso L, Castellazzi AM, Clerici M, Giovannini M, Morelli L, et al. Probiotics and health: an evidence-based review. Pharmacol Res 2011;63:366-76.

20 Pelucchi C, Chatenoud L, Turati F, Galeone C, Moja L, Bach JF, et al. Probiotics supplementation during pregnancy or infancy for the prevention of atopic dermatitis: a meta-analysis. Epidemiology 2012;23:402-14.

21 Dotterud CK, Storro O, Johnsen R, Oien T. Probiotics in pregnant women to prevent allergic disease: a randomized, double-blind trial. Br J Dermatol 2010;163:616-23. 


\section{What is already known on this topic}

Asthma is the most common chronic disease of childhood, and is frequently preceded by wheeze Increases in asthma prevalence have been partly attributed to disruption of the commensal gut microbiota in early life Perinatal probiotics have been shown to prevent atopic dermatitis, but uncertainty remains regarding their effectiveness in asthma prevention

\section{What this study adds}

We found no evidence to support a protective association between perinatal probiotics and childhood asthma or wheeze. Although inadequately reported, probiotic supplementation could be associated with increases in lower respiratory tract infections Additional basic research and adequately powered long term clinical trials are needed to fully define the role of probiotics in the prevention of asthma Probiotics cannot be recommended for primary prevention of childhood asthma or wheeze at this time

22 Yu J, Jang SO, Kim BJ, Song YH, Kwon JW, Kang MJ, et al. The effects of Lactobacillus rhamnosus on the prevention of asthma in a murine model. Allergy Asthma Immunol Res 2010;2:199-205.

23 Blumer N, Sel S, Virna S, Patrascan CC, Zimmermann S, Herz U, et al. Perinatal maternal application of Lactobacillus rhamnosus $G G$ suppresses allergic airway inflammation in mouse offspring. Clin Exp Allergy 2007;37:348-57.

24 Osborn DA, Sinn JK. Probiotics in infants for prevention of allergic disease and food hypersensitivity. Cochrane Database Syst Rev 2007;4:CD006475

25 Abrahamsson TR, Jakobsson T, Bottcher MF, Fredrikson M, Jenmalm MC, Bjorksten B, et al. Probiotics in prevention of IgE-associated eczema: a double-blind, randomized, placebo-controlled trial. J Allergy Clin Immunol 2007;119:1174-80.

26 Kalliomaki M, Salminen S, Arvilommi H, Kero P, Koskinen P, Isolauri E. Probiotics in primary prevention of atopic disease: a randomised placebo-controlled trial. Lancet 2001;357:1076-9.

27 Taylor AL, Dunstan JA, Prescott SL. Probiotic supplementation for the first 6 months of life fails to reduce the risk of atopic dermatitis and increases the risk of allergen sensitization in high-risk children: a randomized controlled trial. J Allergy Clin Immunol 2007;119:184-91.

28 Abrahamsson TR, Jakobsson T, Bjorksten B, Oldaeus G, Jenmalm MC. No effect of probiotics on respiratory allergies: a seven-year follow-up of a randomized controlled trial in infancy. Pediatr Allergy Immunol 2013;24:556-61.

29 Jensen MP, Meldrum S, Taylor AL, Dunstan JA, Prescott SL. Early probiotic supplementation for allergy prevention: Iong-term outcomes. J Allergy Clin Immunol 2012;130:1209-11.e5.

30 Kalliomaki M, Salminen S, Poussa T, Isolauri E. Probiotics during the first 7 years of life: a cumulative risk reduction of eczema in a randomized, placebo-controlled trial. J Allergy Clin Immunol 2007;119:1019-21.

31 Prescott SL, Wiltschut J, Taylor A, Westcott L, Jung W, Currie H, et al. Early markers of allergic disease in a primary prevention study using probiotics: 2.5 -year follow-up phase. Allergy 2008;63:1481-90.

32 Kukkonen K, Savilahti E, Haahtela T, Juntunen-Backman K, Korpela R, Poussa T, et al. Probiotics and prebiotic galacto-oligosaccharides in the prevention of allergic diseases: a randomized, double-blind, placebo-controlled trial. J Allergy Clin Immuno 2007;119:192-8.

33 Niers L, Martin R, Rijkers G, Sengers F, Timmerman H, van Uden N, et al. The effects of selected probiotic strains on the development of eczema (the PandA study). Allergy 2009;64:1349-58.

34 Ou CY, Kuo HC, Wang L, Hsu TY, Chuang H, Liu CA, et al. Prenatal and postnatal probiotics reduces maternal but not childhood allergic diseases: a randomized, double-blind, placebo-controlled trial. Clin Exp Allergy 2012;42:1386-96.

35 West CE, Hammarstrom ML, Hernell O. Probiotics during weaning reduce the incidence of eczema. Pediatr Allergy Immunol 2009;20:430-7.

36 Wickens K, Black PN, Stanley TV, Mitchell E, Fitzharris P, Tannock GW, et al. A differentia effect of 2 probiotics in the prevention of eczema and atopy: a double-blind, randomized, placebo-controlled trial. J Allergy Clin Immunol 2008;122:788-94.

37 Azad MB, Coneys G, Field C, Ramsey C, Becker AB, Abou-Setta A, et al. Probiotic supplementation during pregnancy or infancy for the prevention of wheeze and asthma: a systematic review and meta-analysis. PROSPERO: International prospective register of systematic reviews 2013;CRD42013004385.

38 Higgins JPT, Green S. Cochrane handbook for systematic reviews of interventions version 5.1.0. Cochrane Collaboration, 2011

39 Liberati A, Altman DG, Tetzlaff J, Mulrow C, Gotzsche PC, loannidis JP, et al. The PRISMA statement for reporting systematic reviews and meta-analyses of studies that evaluate healthcare interventions: explanation and elaboration. BMJ 2009;339:b2700.

40 Castro-Rodriguez JA, Holberg CJ, Wright AL, Martinez FD. A clinical index to define risk of asthma in young children with recurrent wheezing. Am J RespirCrit Care Med 2000;162:1403-6.

41 Stein RT. Long-term airway morbidity following viral LRTI in early infancy: recurrent wheezing or asthma? Paediatr Respir Rev 2009;10(suppl 1):29-31.

42 Herzog R, Cunningham-Rundles S. Pediatric asthma: natural history, assessment, and treatment. Mt Sinai J Med 2011;78:645-60.

43 Higgins JP, Altman DG, Gotzsche PC, Juni P, Moher D, Oxman AD, et al. The Cochrane Collaboration's tool for assessing risk of bias in randomised trials. BMJ 2011:343:d5928.

44 Review Manager (RevMan) version 5.2 [program]. Nordic Cochrane Centre, Cochrane Collaboration, 2012.

45 Bradburn MJ, Deeks JJ, Berlin JA, Russell Localio A. Much ado about nothing: a comparison of the performance of meta-analytical methods with rare events. Stat Med 2007;26:53-77.

46 Higgins JP. Thompson SG. Quantifying heterogeneity in a meta-analysis. Stat Med 2002;21:1539-58.

47 Biostat. Comprehensive Meta-Analysis version 2 [program]. Biostat, 2005.

48 Allen SJ, Jordan S, Storey M, Thornton CA, Gravenor M, Garaiova I, et al. Dietary supplementation with lactobacilli and bifidobacteria is well tolerated and not associated with adverse events during late pregnancy and early infancy. J Nutr 2010;140:483-8.
49 Boyle RJ, Ismail IH, Kivivuori S, Licciardi PV, Robins-Browne RM, Mah LJ, et al. Lactobacillus GG treatment during pregnancy for the prevention of eczema: a randomized controlled trial. Allergy 2011;66:509-16.

50 Chouraqui JP, Grathwohl D, Labaune JM, Hascoet JM, de Montgolfier I, Leclaire M, et al. Assessment of the safety, tolerance, and protective effect against diarrhea of infant formulas containing mixtures of probiotics or probiotics and prebiotics in a randomized controlled trial. Am J Clin Nutr 2008:87:1365-73.

51 Gore C, Custovic A, Tannock GW, Munro K, Kerry G, Johnson K, et al. Treatment and secondary prevention effects of the probiotics Lactobacillus paracasei or Bifidobacterium lactis on early infant eczema: randomized controlled trial with follow-up until age 3 years. Clin Exp Allergy 2012;42:112-22.

52 Gruber C, Wendt M, Sulser C, Lau S, Kulig M, Wahn U, et al. Randomized, placebo-controlled trial of Lactobacillus rhamnosus $G G$ as treatment of atopic dermatitis in infancy. Allergy 2007;62:1270-6.

53 Hascoet JM, Hubert C, Rochat F, Legagneur H, Gaga S, Emady-Azar S, et al. Effect of formula composition on the development of infant gut microbiota. J Pediatr Gastroenterol Nutr 2011;52:756-62.

54 Hol J, van Leer EH, Elink Schuurman BE, de Ruiter LF, Samsom JN, Hop W, et al. The acquisition of tolerance toward cow's milk through probiotic supplementation: a randomized, controlled trial. J Allergy Clin Immunol 2008;121:1448-54.

55 Kopp MV, Hennemuth I, Heinzmann A, Urbanek R. Randomized, double-blind, placebo-controlled trial of probiotics for primary prevention: no clinical effects of Lactobacillus GG supplementation. Pediatrics 2008;121:e850-6.

56 Maldonado J, Canabate F, Sempere L, Vela F, Sanchez AR, Narbona E, et al. Human milk probiotic Lactobacillus fermentum CECT5716 reduces the incidence of gastrointestinal and upper respiratory tract infections in infants. J Pediatr Gastroenterol Nutr 2012:54:55-61.

57 Puccio G, Cajozzo C, Meli F, Rochat F, Grathwohl D, Steenhout P. Clinical evaluation of a new starter formula for infants containing live Bifidobacterium longum BL999 and prebiotics. Nutrition 2007;23:1-8.

58 van der Aa LB, van Aalderen WM, Heymans HS, Henk Sillevis Smitt J, Nauta AJ, Knippels LM, et al. Synbiotics prevent asthma-like symptoms in infants with atopic dermatitis. Allergy 2011;66:170-7.

59 Abrahamsson TR, Sandberg Abelius M, Forsberg A, Bjorksten B, Jenmalm MC. A Th1/Th2-associated chemokine imbalance during infancy in children developing eczema, wheeze and sensitization. Clin Exp Allergy 2011;41:1729-39.

60 van der Aa LB, Heymans HS, van Aalderen WM, Sillevis Smitt JH, Knol J, Ben Amor K, et al. Effect of a new synbiotic mixture on atopic dermatitis in infants: a randomized-controlled trial. Clin Exp Allergy 2010:40:795-804

61 West CE, Gothefors L, Granstrom M, Kayhty H, Hammarstrom ML, Hernell O. Effects of feeding probiotics during weaning on infections and antibody responses to diphtheria, tetanus and Hib vaccines. Pediatr Allergy Immunol 2008;19:53-60.

62 Dekker JW, Wickens K, Black PN, Stanley TV, Micthell EA, Fitzharris P. Safety aspects of probiotic bacterial strains Lactobacillus rhamnosus HN001 and Bifidobacterium animalis subsp. lactis HN019 in human infants aged 0 to 2 years. Int Dairy J 2009;19:149-54.

63 Kalliomaki M, Salminen S, Poussa T, Arvilommi H, Isolauri E. Probiotics and prevention of atopic disease: 4-year follow-up of a randomised placebo-controlled trial. Lancet 2003;361:1869-71

64 Kuitunen M, Kukkonen K, Juntunen-Backman K, Korpela R, Poussa T, Tuure T, et al. Probiotics prevent IgE-associated allergy until age 5 years in cesarean-delivered children but not in the total cohort. J Allergy Clin Immunol 2009;123:335-41.

65 Kukkonen AK, Kuitunen M, Savilahti E, Pelkonen A, Malmberg P, Makela M. Airway inflammation in probiotic-treated children at 5 years. Pediatr Allergy Immunol 2011;22:249-51.

66 Wickens K, Black P, Stanley TV, Mitchell E, Barthow C, Fitzharris P, et al. A protective effect of Lactobacillus rhamnosus HN001 against eczema in the first 2 years of life persists to age 4 years. Clin Exp Allergy 2012;42:1071-9.

67 West CE, Hammarstrom ML, Hernell O. Probiotics in primary prevention of allergic disease - follow-up at 8-9 years of age. Allergy 2013;68:1015-20.

68 Wickens K, Stanley TV, Mitchell EA, Barthow C, Fitzharris P, Purdie G, et al. Early supplementation with Lactobacillus rhamnosus HN001 reduces eczema prevalence to 6 years: does it also reduce atopic sensitization? Clin Exp Allergy 2013;43:1048-57.

69 Dotterud C, Oien T, Storro O, Johnsen R. Probiotic supplementation given to mothers in primary prevention of allergic diseases in early childhood - a randomised, double-blind, placebocontrolled trial in a nonselected population [abstract]. Allergy 2009;64(suppl 90):64

70 Hascoet JM, Chouraqui JP, Putet G, Gold F, Simeoni U. Evaluation of growth and incidence of diarrhea with a starter infant formula containing Bifidobacterium longum, Lactobacillus rhamnosus or Lactobacillus paracasei and a mixture of prebiotics [abstract]. Pediatr Acad Soc 2007;7355.6.

71 Kuitunen M, Juntunen-Backman K, Korpela R, Poussa T, Tuure T, Haahtela T, et al. Probiotics prevent IgE-associated allergy until age 5 in cesarean-delivered children but not in the total cohort [abstract]. Allergy 2009;64(suppl. 90):64.

72 Puccio G, Cajozzo C, Steenhout P, Rochat F, Fichot MC, Meli F. Growth of infants fed a starter formula containing bifidobacterium longum bl999 and a mixture of prebiotics [abstract]. Eur J Pediatr 2006;165(suppl 1):115. 
73 Van Der Aa L, Heymans H, Van Aalderen W, Sillevis Smitt H, Nauta A, Knippels L, et al. Specific synbiotic mixture prevents asthma-like symptoms in infants with atopic dermatitis [abstract]. Allergy 2010;65(suppl 92):313.

74 Wickens K, Black P, Stanley T, Mitchell E, Barthow C, Fitzharris P, et al. A differentia effect of two probiotics on allergic disease to age 4 years [abstract]. Allergy 2010;65(supp 92):751.

75 Wickens K, Black P, Stanley T, Mitchell E, Barthow C, Fitzharris P, et al. A differentia effect of 2 probiotics on allergic disease to age 4 years [abstract]. J Allergy Clin Immunology 2011;127(suppl 2):AB38.

76 Wickens K, Black P, Stanley TV, Mitchell E, Barthow C, Fitzharris P, et al. A differential effect of 2 probiotics on allergic disease to age 4 years [abstract]. Intern Med $J$ 2010;40(suppl 4):19-20.

77 Roberfroid M. Prebiotics: the concept revisited. J Nutr 2007:137:830-7S.

78 Garner R, Kohen D. Changes in the prevalence of asthma among Canadian children. Health Rep 2008;19:45-50.

79 Becker A, Lemiere C, Berube D, Boulet LP, Ducharme FM, FitzGerald M, et al. Summary of recommendations from the Canadian Asthma Consensus guidelines, 2003. CMAJ 2005;173:S3-11.

80 Pedersen SE, Hurd SS, Lemanske RF Jr, Becker A, Zar HJ, Sly PD, et al. Global strategy for the diagnosis and management of asthma in children 5 years and younger. Pediatr Pulmonol 2011;46:1-17.

81 Savenije OE, Granell R, Caudri D, Koppelman GH, Smit HA, Wijga A, et al. Comparison of childhood wheezing phenotypes in 2 birth cohorts: ALSPAC and PIAMA. J Allergy Clin Immunol 2011;127:1505-12.e14.
82 Cabana MD, McKean M, Wong AR, Chao C, Caughey AB. Examining the hygiene hypothesis: the trial of infant probiotic supplementation. Paediatr Perinat Epidemiol 2007;21(suppl 3):23-8.

83 Durackova Z. PROCHILD: probiotics in prevention of respiratory tract infections, ISRCTN28722693 International Standard Randomised Controlled Trial Number Register. 2010. www.controlled-trials.com/ISRCTN28722693/.

84 Sheck LA. Influence of probiotics on atopy with focus on respiratory allergic diseasesfollow-up to 7 years, NCT00826189. ClinicalTrials.gov: US National Institutes of Health, 2009. http://clinicaltrials.gov/ct2/show/study/NCT00826189.

85 Lee J, Bang J, Woo HJ. Immunomodulatory and anti-allergic effects of orally administered lactobacillus species in ovalbumin-sensitized mice. J Microbiol Biotechnol 2013;23:724-30.

$86 \mathrm{Neu} \mathrm{J}$, Rushing J. Cesarean versus vaginal delivery: Iong-term infant outcomes and the hygiene hypothesis. ClinPerinatol 2011;38:321-31.

\section{Accepted: 8 October 2013}

\section{Cite this as: BMJ 2013;347:f6471}

This is an Open Access article distributed in accordance with the Creative Commons Attribution Non Commercial (CC BY-NC 3.0) license, which permits others to distribute, remix, adapt, build upon this work non-commercially, and license their derivative works on different terms, provided the original work is properly cited and the use is non-commercial. See: http://creativecommons.org/licenses/by-nc/3.0/. 


\section{Tables}

\section{Table 1/ Characteristics of included trials and study populations}

\begin{tabular}{|c|c|c|c|c|c|c|c|c|c|c|}
\hline \multirow[b]{2}{*}{$\begin{array}{l}\text { Primary } \\
\text { article }\end{array}$} & \multirow{2}{*}{$\begin{array}{l}\text { Companion } \\
\text { articles }^{*} \\
\text { and } \\
\text { unpublished } \\
\text { data }\end{array}$} & \multirow[b]{2}{*}{$\begin{array}{l}\text { Country, } \\
\text { enrolment } \\
\text { period }\end{array}$} & \multirow[b]{2}{*}{$\begin{array}{l}\text { Age at last } \\
\text { follow-up }\end{array}$} & \multirow[b]{2}{*}{$\begin{array}{c}\text { Number of } \\
\text { participants } †\end{array}$} & \multirow[b]{2}{*}{$\begin{array}{c}\text { Infant } \\
\text { asthma risk }\end{array}$} & \multirow[b]{2}{*}{$\begin{array}{c}\text { Feeding } \\
\text { Restrictions }\end{array}$} & \multirow[b]{2}{*}{$\begin{array}{c}\text { Caesarean } \\
\text { delivery } \\
\text { rate }(\%)\end{array}$} & \multicolumn{3}{|c|}{ Relevant outcomes included‡ } \\
\hline & & & & & & & & Asthma & Wheeze & LRTI \\
\hline West $2009^{35}$ & $\begin{array}{l}\text { West } 2008,{ }^{61} \\
\text { West } 2013^{67}\end{array}$ & $\begin{array}{l}\text { Sweden, } \\
2000-03\end{array}$ & 8 years & 179 infants & Unselected & None & 0 & Yes & Yes (I) & - \\
\hline $\begin{array}{l}\text { Abrahamsson } \\
2007^{25}\end{array}$ & $\begin{array}{c}\text { Abrahamsson } \\
2013^{28} \\
\end{array}$ & $\begin{array}{l}\text { Sweden, } \\
2001-03\end{array}$ & 7 years & $\begin{array}{l}239 \text { mothers } \\
\text { (209 infants) }\end{array}$ & $\begin{array}{l}\text { High (family } \\
\text { history) }\end{array}$ & None & 13 & Yes & Yes (I) & - \\
\hline $\begin{array}{l}\text { Kalliomaki } \\
2001^{26}\end{array}$ & $\begin{array}{l}\text { Kalliomaki } \\
2003{ }^{63} \\
\text { Kalliomaki } \\
2007^{30}\end{array}$ & Finland, 1997-98 & 7 years & $\begin{array}{l}159 \text { mothers } \\
\text { (155 infants) }\end{array}$ & $\begin{array}{l}\text { High (family } \\
\text { history) }\end{array}$ & None & Not reported & Yes & - & - \\
\hline Niers $2009^{33}$ & $\begin{array}{c}\text { Gorissen } \\
\text { (unpublished } \\
\text { data), }{ }^{* *} \text { data } \\
\text { provided }\end{array}$ & $\begin{array}{c}\text { Netherlands, } \\
\text { 2004-05 }\end{array}$ & 6 years & $\begin{array}{l}156 \text { mothers } \\
\text { (123 infants) }\end{array}$ & $\begin{array}{l}\text { High (family } \\
\text { history) }\end{array}$ & None & 10 & Yes & Yes (I) & - \\
\hline $\begin{array}{l}\text { Wickens } \\
2008^{36}\end{array}$ & $\begin{array}{l}\text { Wickens } 2012^{66} \\
\text { Wickens } 2013^{68}\end{array}$ & $\begin{array}{c}\text { New Zealand, } \\
2004-05\end{array}$ & 6 years & $\begin{array}{l}512 \text { mothers } \\
\text { (474 infants) }\end{array}$ & $\begin{array}{l}\text { High (family } \\
\text { history) }\end{array}$ & None & 32 & Yes & Yes (I) & - \\
\hline $\begin{array}{l}\text { Kukkonen } \\
2007^{32}\end{array}$ & $\begin{array}{c}\text { Kuitunen } \\
2009,{ }^{64} \text { data } \\
\text { provided }\end{array}$ & Finland, 2000-03 & 5 years & $\begin{array}{l}1223 \text { mothers } \\
\text { (1018 infants) }\end{array}$ & $\begin{array}{l}\text { High (family } \\
\text { history) }\end{array}$ & None & 17 & Yes & - & - \\
\hline Taylor $2007^{27}$ & $\begin{array}{c}\text { Prescott } 2008{ }^{31} \\
\text { Jensen } 2012^{29}\end{array}$ & $\begin{array}{l}\text { Australia, } \\
2002-05\end{array}$ & 5 years & $\begin{array}{l}226 \text { mothers } \\
\text { (218 infants) }\end{array}$ & $\begin{array}{l}\text { High (family } \\
\text { history) }\end{array}$ & None & 44 & Yes & Yes $(I, R)$ & Yes \\
\hline Gore $2012^{51}$ & None & UK, 2002-04 & 3 years & 137 infants§ & High (eczema) & $\begin{array}{l}\text { FF required, } \\
\text { BF permitted }\end{array}$ & Not reported & Yesף & Yes (I) & - \\
\hline Ou $2012^{34}$ & None & Taiwan, 2002-06 & 3 years & $\begin{array}{l}191 \text { mothers } \\
\text { (151 infants) }\end{array}$ & $\begin{array}{l}\text { High (family } \\
\text { history) }\end{array}$ & None & Not reported & Yes & - & - \\
\hline $\begin{array}{l}\text { Dotterud } \\
2010^{21} \\
\end{array}$ & None & Norway, 2003-05 & 2 years & $\begin{array}{l}415 \text { mothers } \\
\text { (363 infants) }\end{array}$ & Unselected & $\mathrm{BF}$ required & Not reported & Yes & - & - \\
\hline Kopp $2008^{55}$ & None & $\begin{array}{l}\text { Germany, } \\
2002-04\end{array}$ & 2 years & $\begin{array}{l}105 \text { mothers } \\
\text { (104 infants) }\end{array}$ & $\begin{array}{l}\text { High (family } \\
\text { history) }\end{array}$ & None & 19 & - & Yes (R) & - \\
\hline $\begin{array}{l}\text { van der Aa } \\
2011^{58}\end{array}$ & $\begin{array}{c}\text { van der } \mathrm{Aa} \\
2010^{60}\end{array}$ & $\begin{array}{c}\text { Netherlands, } \\
\text { 2005-07 }\end{array}$ & 18 months & 90 infants & High (eczema) & $\begin{array}{l}\text { Exclusive FF } \\
\text { at enrolment }\end{array}$ & 18 & - & Yes (R) & - \\
\hline Hol $2008^{54}$ & Data provided & $\begin{array}{c}\text { Netherlands, } \\
\text { 2004-07 }\end{array}$ & 16 months & 119 infants & $\begin{array}{l}\text { High (milk } \\
\text { allergy) }\end{array}$ & $\begin{array}{l}\text { Exclusive FF } \\
\text { at enrolment }\end{array}$ & 19 & - & Yes (I) & - \\
\hline Boyle $2011^{49}$ & None & $\begin{array}{l}\text { Australia, } \\
2006-08\end{array}$ & 12 months & $\begin{array}{l}250 \text { mothers } \\
\text { (250 infants) }\end{array}$ & $\begin{array}{l}\text { High (family } \\
\text { history) }\end{array}$ & None & 27 & - & Yes (I) & - \\
\hline $\begin{array}{l}\text { Maldonado } \\
2012^{56}\end{array}$ & None & Spain, 2008-09 & 12 months & 215 infants & Unselected & $\begin{array}{l}\text { Exclusive FF } \\
\text { at enrolment }\end{array}$ & 45 & - & - & Yes \\
\hline $\begin{array}{l}\text { Chouraqui } \\
2008^{50}\end{array}$ & None & France, 2004-05 & 12 months & 284 infants & Unselected & $\begin{array}{l}\text { Exclusive FF } \\
\text { at enrolment }\end{array}$ & 17 & - & - & Yes \\
\hline Gruber $2007^{52}$ & None & $\begin{array}{c}\text { Germany, not } \\
\text { reported }\end{array}$ & 10 months & 106 infants & High (eczema) & None & Not reported & - & - & Yes \\
\hline Allen $2010^{48}$ & None & $\begin{array}{c}\text { UK, not reported } \\
(2004)\end{array}$ & 6 months & $\begin{array}{l}454 \text { mothers } \\
\text { (454 infants) }\end{array}$ & $\begin{array}{l}\text { High (family } \\
\text { history) }\end{array}$ & None & Not reported & - & - & Yes \\
\hline $\begin{array}{l}\text { Hascoet } \\
2011^{53} \\
\end{array}$ & None & $\begin{array}{c}\text { France, not } \\
\text { reported (2006) }\end{array}$ & 4 months & 79 infants§ & Unselected & $\begin{array}{l}\text { Exclusive FF } \\
\text { at enrolment }\end{array}$ & 8 & - & - & Yes \\
\hline Puccio $2007^{57}$ & Data provided & $\begin{array}{l}\text { Italy, not } \\
\text { reported }\end{array}$ & 4 months & 138 infants & Unselected & $\begin{array}{l}\text { Exclusive FF } \\
\text { at enrolment }\end{array}$ & 40 & - & Yes (I) & - \\
\hline
\end{tabular}

Trials are listed in order of decreasing duration of follow-up.

$\mathrm{BF}=$ breastfeeding; $F F=$ formula feeding; LRTI=lower respiratory tract infection.

*Excludes conference abstracts from which no unique data were extracted.

†Indicates mothers or infants randomised; where recruitment occurred prenatally, includes number of infants eligible at birth (in brackets).

¥l=incident wheeze; R=recurrent wheeze.

$\S$ Trial included additional groups (for example, observational) not considered in this review. 
Table 1 (continued)

\begin{tabular}{|c|c|c|c|c|c|c|c|c|c|c|}
\hline \multirow[b]{2}{*}{$\begin{array}{l}\text { Primary } \\
\text { article }\end{array}$} & \multirow{2}{*}{$\begin{array}{l}\text { Companion } \\
\text { articles }^{\star} \\
\text { and } \\
\text { unpublished } \\
\text { data }\end{array}$} & \multirow[b]{2}{*}{$\begin{array}{l}\text { Country, } \\
\text { enrolment } \\
\text { period }\end{array}$} & \multirow[b]{2}{*}{$\begin{array}{l}\text { Age at last } \\
\text { follow-up }\end{array}$} & \multirow[b]{2}{*}{$\begin{array}{c}\text { Number of } \\
\text { participants } †\end{array}$} & \multirow[b]{2}{*}{$\begin{array}{c}\text { Infant } \\
\text { asthma risk }\end{array}$} & \multirow[b]{2}{*}{$\begin{array}{c}\text { Feeding } \\
\text { Restrictions }\end{array}$} & \multirow[b]{2}{*}{$\begin{array}{c}\text { Caesarean } \\
\text { delivery } \\
\text { rate }(\%)\end{array}$} & \multicolumn{3}{|c|}{ Relevant outcomes includedł } \\
\hline & & & & & & & & Asthma & Wheeze & LRTI \\
\hline
\end{tabular}

IThis trial reported asthma outcomes in the text only, and the authors declined to provide data for meta-analysis.

**Unpublished data from a forthcoming report provided by Gorissen DMW, Rutten NBMM, Oostermeijer CMJ, Niers LEM, Hoekstra MO, Rijkers GT, et al. Preventive effects of selected probiotic strains on the development of asthma and allergic rhinitis in childhood. The PandA study. 


\begin{tabular}{|c|c|c|c|c|c|c|c|}
\hline Primary article & $\begin{array}{l}\text { Prenatal or } \\
\text { postnatal } \\
\text { intervention }\end{array}$ & $\begin{array}{l}\text { Participant } \\
\text { receiving } \\
\text { probiotics }\end{array}$ & $\begin{array}{l}\text { Duration of } \\
\text { intervention } \\
\text { (months) }\end{array}$ & Timing of intervention & Probiotic organism & $\begin{array}{c}\text { Added } \\
\text { prebiotic }\end{array}$ & $\begin{array}{l}\text { Total daily dose } \\
\text { (CFU) }\end{array}$ \\
\hline West $2009^{35}$ & Postnatal & Infant & 10 & Age 4-13 months (infant) & L paracasei F19 & No & $1 \times 10^{8}$ (minimum) \\
\hline $\begin{array}{l}\text { Abrahamsson } \\
2007^{25}\end{array}$ & $\begin{array}{c}\text { Prenatal and } \\
\text { postnatal }\end{array}$ & Mother and infant & 13 & $\begin{array}{l}36 \text { WG to delivery (mother), } \\
\text { birth to } 12 \text { months (infant) }\end{array}$ & L reuteri & No & $1 \times 10^{8}$ \\
\hline Kalliomaki $2001^{26}$ & $\begin{array}{l}\text { Prenatal and } \\
\text { postnatal }\end{array}$ & $\begin{array}{l}\text { Mother and infant } \\
\text { (if not breastfed) }\end{array}$ & 6.5 & $\begin{array}{l}\text { 36-38 WG to } 6 \text { months } \\
\text { postpartum if breastfeeding } \\
\text { (mother), weaning to } 6 \text { months } \\
\text { (infant) }\end{array}$ & L rhamnosus GG & No & $2 \times 10^{10}$ \\
\hline Niers $2009^{33}$ & $\begin{array}{l}\text { Prenatal and } \\
\text { postnatal }\end{array}$ & Mother and infant & 14 & $\begin{array}{l}24 \text { WG to delivery (mother), } \\
\text { birth to } 3 \text { months (infant) }\end{array}$ & $\begin{array}{l}\text { B bifidum W23, B lactis } \\
\text { W52, and } L \text { lactis W58 }\end{array}$ & No & $3 \times 10^{9}$ \\
\hline Wickens $2008^{36}$ & $\begin{array}{l}\text { Prenatal and } \\
\text { postnatal }\end{array}$ & Mother and infant & 25 & $\begin{array}{l}35 \text { WG to } 6 \text { months postpartum } \\
\text { if breastfeeding (mother), birth } \\
\text { to } 2 \text { years (infant) }\end{array}$ & $\begin{array}{l}2 \text { probiotic groups: } L \\
\text { rhamnosus HNO01 or } B \\
\text { lactis } \mathrm{HN} 019\end{array}$ & No & $\begin{array}{c}6 \times 10^{9}(\mathrm{HN} 001) \\
\text { or } \\
9 \times 10^{9}(\mathrm{HN} 019)\end{array}$ \\
\hline Kukkonen $2007^{32}$ & $\begin{array}{l}\text { Prenatal and } \\
\text { postnatal }\end{array}$ & Mother and infant & 7 & $\begin{array}{l}\text { 36-38 WG to delivery (mother), } \\
\text { birth to } 6 \text { months (infant) }\end{array}$ & $\begin{array}{c}L \text { rhamnosus GG, } L \\
\text { rhamnosus } \mathrm{LC705,} B \text { breve } \\
\text { Bb-99, and } \\
\text { Propionibacterium } \\
\text { freudenreichii JS }\end{array}$ & Yes & $\begin{array}{c}2.4 \times 10^{10} \\
\text { (mother) } \\
1.2 \times 10^{10} \text { (infant) }\end{array}$ \\
\hline Taylor $2007^{27}$ & Postnatal & Infant & 6 & Birth to 6 months (infant) & L acidophilus LAVRI-A1 & No & $3 \times 10^{9}$ \\
\hline Gore $2012^{51}$ & Postnatal & Infant & 3 & Age 5-8 months (infant) & $\begin{array}{l}2 \text { probiotic groups: } L \\
\text { paracasei or } B \text { lactis }\end{array}$ & No & $1 \times 10^{10}$ \\
\hline Ou $2012^{34}$ & $\begin{array}{l}\text { Prenatal and } \\
\text { postnatal }\end{array}$ & $\begin{array}{l}\text { Mother and infant } \\
\text { (if not breastfed) }\end{array}$ & 10 & $\begin{array}{l}24 \text { WG to } 6 \text { months postpartum } \\
\text { if breastfeeding (mother), } \\
\text { weaning to } 6 \text { months (infant) }\end{array}$ & L rhamnosus GG & No & $1 \times 10^{10}$ \\
\hline Dotterud $2010^{21}$ & $\begin{array}{l}\text { Prenatal and } \\
\text { postnatal }\end{array}$ & Mother & 4 & $\begin{array}{c}36 \text { WG to } 3 \text { months postpartum } \\
\text { (mother) }\end{array}$ & $\begin{array}{c}\text { L rhamnosus GG, } B \text { lactis } \\
\text { Bb-12, and } L \text { acidophilus } \\
\text { La-5 } 5\end{array}$ & No & $1.05 \times 10^{11}$ \\
\hline Kopp $2008^{55}$ & $\begin{array}{l}\text { Prenatal and } \\
\text { postnatal }\end{array}$ & Mother and infant & 7 & $\begin{array}{l}\text { 34-36 WG to } 3 \text { months } \\
\text { postpartum, if breastfeeding } \\
\text { (mother), weaning to } 6 \text { months, } \\
\text { or 3-6 months (infant) }\end{array}$ & L rhamnosus GG & No & $1 \times 10^{10}$ \\
\hline van der Aa $2011^{58}$ & Postnatal & Infant & 3 & Age 5-8 months (infant) & $B$ breve $\mathrm{M}-16 \mathrm{~V}$ & Yes & $\begin{array}{c}1.3 \times 10^{6} \text { per } 100 \\
\mathrm{~mL} \dagger\end{array}$ \\
\hline Hol $2008^{54}$ & Postnatal & Infant & 12 & Age 4-16 months (infant) & L casei and B lactis Bb-12 & No & $2 \times 10^{7}$ per g $\dagger$ \\
\hline Boyle $2011^{49}$ & Prenatal & Mother & 1 & 36 WG to delivery (mother) & L rhamnosus GG & No & $1.8 \times 10^{10}$ \\
\hline $\begin{array}{l}\text { Maldonado } \\
2012^{56}\end{array}$ & Postnatal & Infant & 6 & Age 6-12 months (infant) & $L$ fermentum CECT5716 & Yes & $2 \times 10^{8}$ (average) \\
\hline Chouraqui $2008^{50}$ & Postnatal & Infant & 4 & $\begin{array}{c}\text { Age } 2 \text { weeks to } 4 \text { months } \\
\text { (infant) }\end{array}$ & $\begin{array}{l}3 \text { probiotic groups: } B \text { longum } \\
\text { BL999 and } L \text { rhamnosus } \\
\text { LPR; BL999 and LPR plus } \\
\text { prebiotic; or BL999 and } L \\
\text { paracasei ST11 plus } \\
\text { prebiotic }\end{array}$ & Yes & $\begin{array}{c}5-8 \times 10^{8} \text { per } 100 \\
\mathrm{~mL} \dagger\end{array}$ \\
\hline Gruber $2007^{52}$ & Postnatal & Infant & 3 & Age 7-10 months (infant) & L rhamnosus GG & No & $1 \times 10^{10}$ \\
\hline Allen $2010^{48}$ & $\begin{array}{l}\text { Prenatal and } \\
\text { postnatal }\end{array}$ & Mother and infant & 7 & $\begin{array}{l}36 \text { WG to delivery (mother), } \\
\text { birth to } 6 \text { months (infant) }\end{array}$ & $\begin{array}{c}\text { L salivarius CUL61, } L \\
\text { paracasei CUL08, B lactis } \\
\text { CUL34, and } B \text { bifidum } \\
\text { CUL20 }\end{array}$ & No & $1 \times 10^{10}$ \\
\hline Hascoet $2011^{53}$ & Postnatal & Infant & 4 & Age 4 days to 4 months (infant) & B longum BL999 & No & $2 \times 10^{7}$ per g† \\
\hline Puccio $2007^{57}$ & Postnatal & Infant & 3.7 & Age 2-16 weeks (infant) & B longum BL999 & Yes & $2 \times 10^{7}$ per g† \\
\hline
\end{tabular}




\begin{tabular}{|c|c|c|c|c|c|c|}
\hline \multirow[b]{2}{*}{ Subgroup } & \multicolumn{3}{|c|}{ Diagnosed asthma } & \multicolumn{3}{|c|}{ Incident wheeze } \\
\hline & No of Studies & Pooled risk ratio $(95 \% \mathrm{Cl})$ & $I^{2}(\%)$ & $\begin{array}{l}\text { No of } \\
\text { Studies }\end{array}$ & Pooled risk ratio $(95 \% \mathrm{Cl})$ & $I^{2}(\%)$ \\
\hline Overall & 9 & $0.99(0.81$ to 1.21$)$ & 0 & 9 & $0.97(0.87$ to 1.09$)$ & 0 \\
\hline \multicolumn{7}{|c|}{ Participant receiving intervention } \\
\hline Mother & 1 & $0.64(0.27$ to 1.54$)$ & - & 1 & 0.93 (0.59 to 1.48$)$ & - \\
\hline Mother and infant & 6 & $1.00(0.80$ to 1.23$)$ & 0 & 3 & $0.96(0.83$ to 1.11$)$ & 0 \\
\hline Infant & 2 & 1.27 (0.61 to 2.66$)$ & 0 & 5 & $1.00(0.78$ to 1.28$)$ & 26 \\
\hline \multicolumn{7}{|l|}{ Timing of intervention } \\
\hline Prenatal & 0 & - & - & 1 & $0.93(0.59$ to 1.48$)$ & - \\
\hline Prenatal and postnatal & 7 & 0.97 (0.79 to 1.19$)$ & 0 & 3 & $0.96(0.83$ to 1.11$)$ & 0 \\
\hline Postnatal & 2 & 1.27 (0.61 to 2.66$)$ & 0 & 5 & $1.00(0.78$ to 1.28$)$ & 26 \\
\hline \multicolumn{7}{|l|}{ Duration of intervention } \\
\hline smedian (6 months) & 2 & 0.98 (0.39 to 2.45$)$ & 43 & 4 & $0.93(0.73$ to 1.19$)$ & 1 \\
\hline$>$ median & 7 & 0.99 (0.81 to 1.23$)$ & 0 & 5 & 0.98 (0.86 to 1.12$)$ & 2 \\
\hline \multicolumn{7}{|l|}{ Probiotic dose } \\
\hline$<$ median ( $10^{10} \mathrm{CFU}$ daily) & 5 & 0.98 (0.74 to 1.31$)$ & 0 & 5 & $1.04(0.87$ to 1.24$)$ & 23 \\
\hline$\geq$ median & 4 & 1.06 (0.68 to 1.66$)$ & 38 & 2 & $0.79(0.56$ to 1.11$)$ & 0 \\
\hline Fed without restraint & 0 & - & - & 2 & $0.97(0.76$ to 1.25$)$ & 0 \\
\hline \multicolumn{7}{|l|}{ Probiotic organism* } \\
\hline Bifidobacterium species & 1 & 1.04 (0.63 to 1.71$)$ & - & 3 & $0.96(0.80$ to 1.16$)$ & 3 \\
\hline Lactobacillus species & 6 & $1.13(0.82$ to 1.55$)$ & 0 & 6 & 0.99 (0.80 to 1.23$)$ & 19 \\
\hline Combination & 3 & 0.86 (0.63 to 1.16$)$ & 0 & 2 & $1.03(0.78$ to 1.37$)$ & 0 \\
\hline \multicolumn{7}{|l|}{ Follow-up durationt } \\
\hline$<3$ years & 6 & 0.90 (0.62 to 1.31$)$ & 0 & 8 & $0.98(0.86$ to 1.11$)$ & 0 \\
\hline 3 to $<6$ years & 4 & 1.04 (0.77 to 1.39$)$ & 0 & 3 & $0.91(0.76$ to 1.10$)$ & 18 \\
\hline$\geq 6$ years & 5 & $1.01(0.76$ to 1.34$)$ & 0 & 2 & 0.99 (0.79 to 1.25$)$ & 47 \\
\hline \multicolumn{7}{|l|}{ Asthma risk } \\
\hline $\begin{array}{l}\text { High (infant atopic } \\
\text { disease) }\end{array}$ & 0 & - & - & 2 & 0.85 (0.65 to 1.12$)$ & 0 \\
\hline High (family history) & 7 & 1.01 (0.82 to 1.25$)$ & 0 & 5 & 0.97 (0.85 to 1.12$)$ & 0 \\
\hline Unselected & 2 & $0.78(0.40$ to 1.51$)$ & 0 & 2 & $1.19(0.76$ to 1.86$)$ & 40 \\
\hline \multicolumn{7}{|l|}{ Infant feeding } \\
\hline Unrestricted & 9 & - & - & 7 & $0.98(0.84$ to 1.15$)$ & 15 \\
\hline Exclusive formula feeding & 0 & - & - & 2 & $0.97(0.76$ to 1.25$)$ & 0 \\
\hline \multicolumn{7}{|l|}{ Caesarean delivery rate } \\
\hline$\leq$ median (19\%) & 4 & 0.92 (0.69 to 1.21$)$ & 0 & 4 & $1.11(0.88$ to 1.41$)$ & 0 \\
\hline$>$ median & 2 & $1.03(0.73$ to 1.45$)$ & 0 & 4 & 0.96 (0.84 to 1.09$)$ & 0 \\
\hline Not reported & 3 & 1.25 (0.57 to 2.74$)$ & 53 & 1 & $0.64(0.38$ to 1.07$)$ & 0 \\
\hline \multicolumn{7}{|l|}{ Geographical area } \\
\hline Europe & 6 & 0.94 (0.72 to 1.22$)$ & 0 & 6 & $1.01(0.83$ to 1.23$)$ & 7 \\
\hline Asia or Oceania & 3 & $1.07(0.78$ to 1.46$)$ & 0 & 3 & $0.95(0.82$ to 1.10$)$ & 0 \\
\hline \multicolumn{7}{|l|}{ Risk of bias } \\
\hline Low or unclear & 2 & $1.47(0.45$ to 4.77$)$ & 71 & 3 & $0.87(0.69$ to 1.10$)$ & 0 \\
\hline High & 7 & $0.98(0.76$ to 1.26$)$ & 0 & 6 & $0.97(0.87$ to 1.09$)$ & 6 \\
\hline \multicolumn{7}{|l|}{ Industry authorship } \\
\hline No or unclear & 7 & 1.05 (0.82 to 1.36$)$ & 0 & 7 & 0.96 (0.84 to 1.08$)$ & 0 \\
\hline Yes & 2 & 0.89 (0.65 to 1.23$)$ & 0 & 2 & 1.09 (0.80 to 1.49$)$ & 0 \\
\hline
\end{tabular}

$\mathrm{CFU}=$ colony forming units. Tables 1 and 2 summarise the studies contributing data for each outcome and subgroup.

${ }^{*}$ Two trials compared Lactobacillus with Bifidobacteria in separate groups. 
Table 3 (continued)

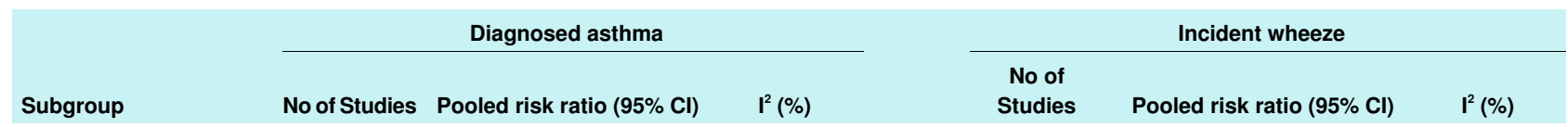

†With regard to subgroup analysis of follow-up duration, based on the number and duration of follow-up assessments, some trials contributed data to more than one predefined subgroup. For all other subgroup analyses, the longest available follow-up data from each trial were used. 


\section{Figures}

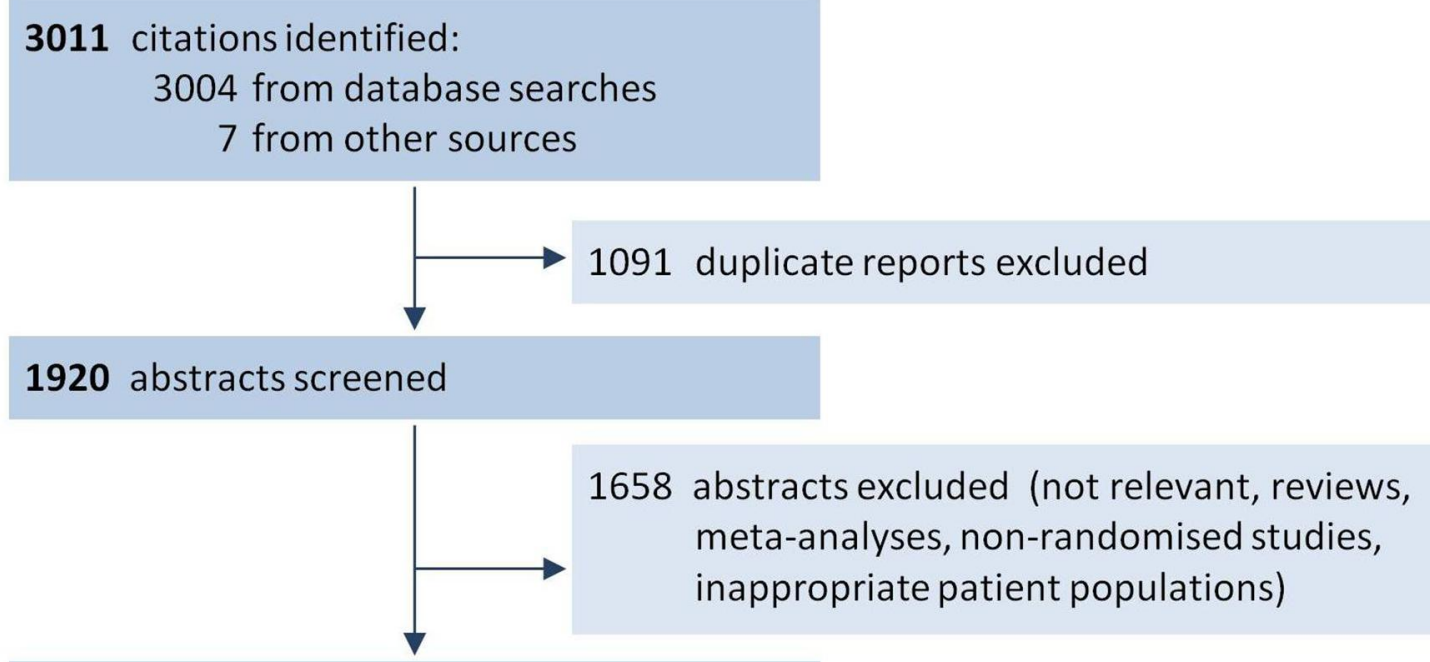

262 full text articles assessed for eligibility

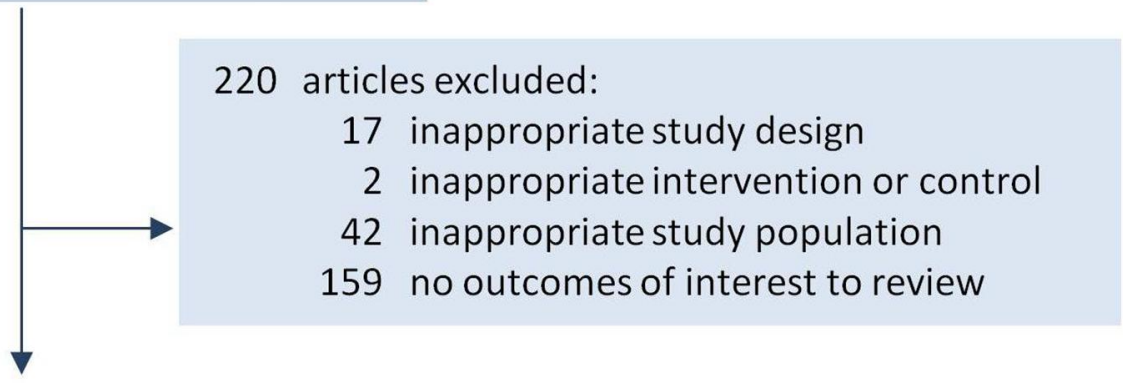

42 citations included in analysis:

20 primary articles (unique trials)

10 extended follow-up articles

4 companion articles

8 duplicate conference abstracts

Fig 1 Study flow diagram, following PRISMA criteria with modifications ${ }^{39}$ 


\begin{tabular}{|c|c|c|c|c|c|c|c|c|}
\hline Study or Subgroup & \multicolumn{2}{|c|}{ Probiotic } & \multicolumn{2}{|c|}{ Placebo } & Weight & $\begin{array}{c}\text { Risk Ratio } \\
\text { M-H, Random, } 95 \% \mathrm{Cl}\end{array}$ & \multicolumn{2}{|c|}{$\begin{array}{c}\text { Risk Ratio } \\
\text { M-H, Random, } 95 \% \mathrm{Cl} \\
\end{array}$} \\
\hline West 2008 & 7 & 89 & 7 & 90 & $4.0 \%$ & $1.01[0.37,2.76]$ & 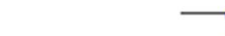 & \\
\hline Abrahamsson 2007 & 14 & 117 & 14 & 115 & $8.3 \%$ & $0.98[0.49,1.97]$ & & \\
\hline Kalliomaki 2001 & 9 & 77 & 3 & 82 & $2.5 \%$ & $3.19[0.90,11.37]$ & & \\
\hline Niers 2009 & 5 & 78 & 8 & 78 & $3.5 \%$ & $0.63[0.21,1.83]$ & & 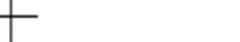 \\
\hline Wickens 2008a (HN001) & 31 & 159 & 17 & 79 & $14.5 \%$ & $0.91[0.54,1.53]$ & & - \\
\hline Wickens 2008b (HN019) & 37 & 158 & 18 & 80 & $16.4 \%$ & $1.04[0.63,1.71]$ & & 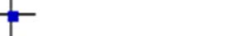 \\
\hline Kukkonen 2007 & 58 & 610 & 63 & 613 & $34.9 \%$ & $0.93[0.66,1.30]$ & & \\
\hline Taylor 2007 & 8 & 111 & 5 & 115 & $3.4 \%$ & $1.66[0.56,4.91]$ & & \\
\hline Ou 2012 & 14 & 95 & 11 & 96 & $7.4 \%$ & $1.29[0.62,2.69]$ & & - \\
\hline Dotterud 2010 & 8 & 211 & 12 & 204 & $5.2 \%$ & $0.64[0.27,1.54]$ & & T \\
\hline Total $(95 \% \mathrm{Cl})$ & & 1705 & & 1552 & $100.0 \%$ & $0.99[0.81,1.21]$ & & \\
\hline Total events & 191 & & 158 & & & & & \\
\hline $\begin{array}{l}\text { Heterogeneity: } \operatorname{Tau}^{2}=0.0 \\
\text { Test for owerall effect: } Z=\end{array}$ & $\begin{array}{l}C h i^{2}=6 \\
10(P=0\end{array}$ & $\begin{array}{l}57, \mathrm{df}= \\
0.92)\end{array}$ & $=9(\mathrm{P}=0$ & $68) ; 1^{2}=$ & $=0 \%$ & & $\begin{array}{lc}0.01 & 0.1 \\
\text { Favours } & \text { Probiotic }\end{array}$ & $\begin{array}{c}10 \\
\text { Favours Placebo }\end{array}$ \\
\hline
\end{tabular}

Fig 2 Probiotic supplementation during pregnancy or infancy and doctor diagnosed asthma in children. The longest available follow-up data (intention to treat) were extracted from each contributing trial. Trials are sorted in order of decreasing duration of follow-up. $\mathrm{df}=$ degrees of freedom; $\mathrm{M}-\mathrm{H}=$ Mantel-Haenszel

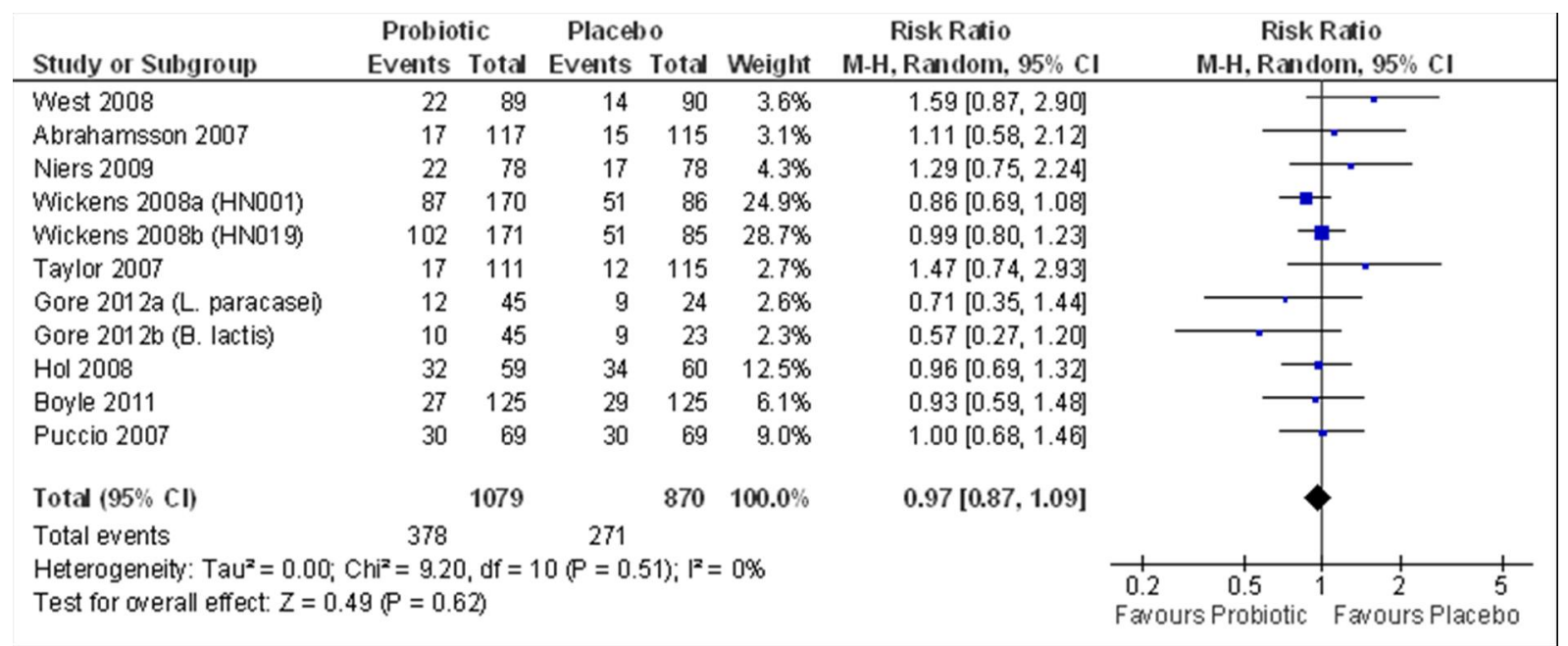

Fig 3 Probiotic supplementation during pregnancy or infancy and incident wheeze in children. The longest available follow-up data (intention to treat) were extracted from each contributing trial. Trials are sorted in order of decreasing duration of follow-up. $\mathrm{df}=$ degrees of freedom; $\mathrm{M}-\mathrm{H}=$ Mantel-Haenszel 


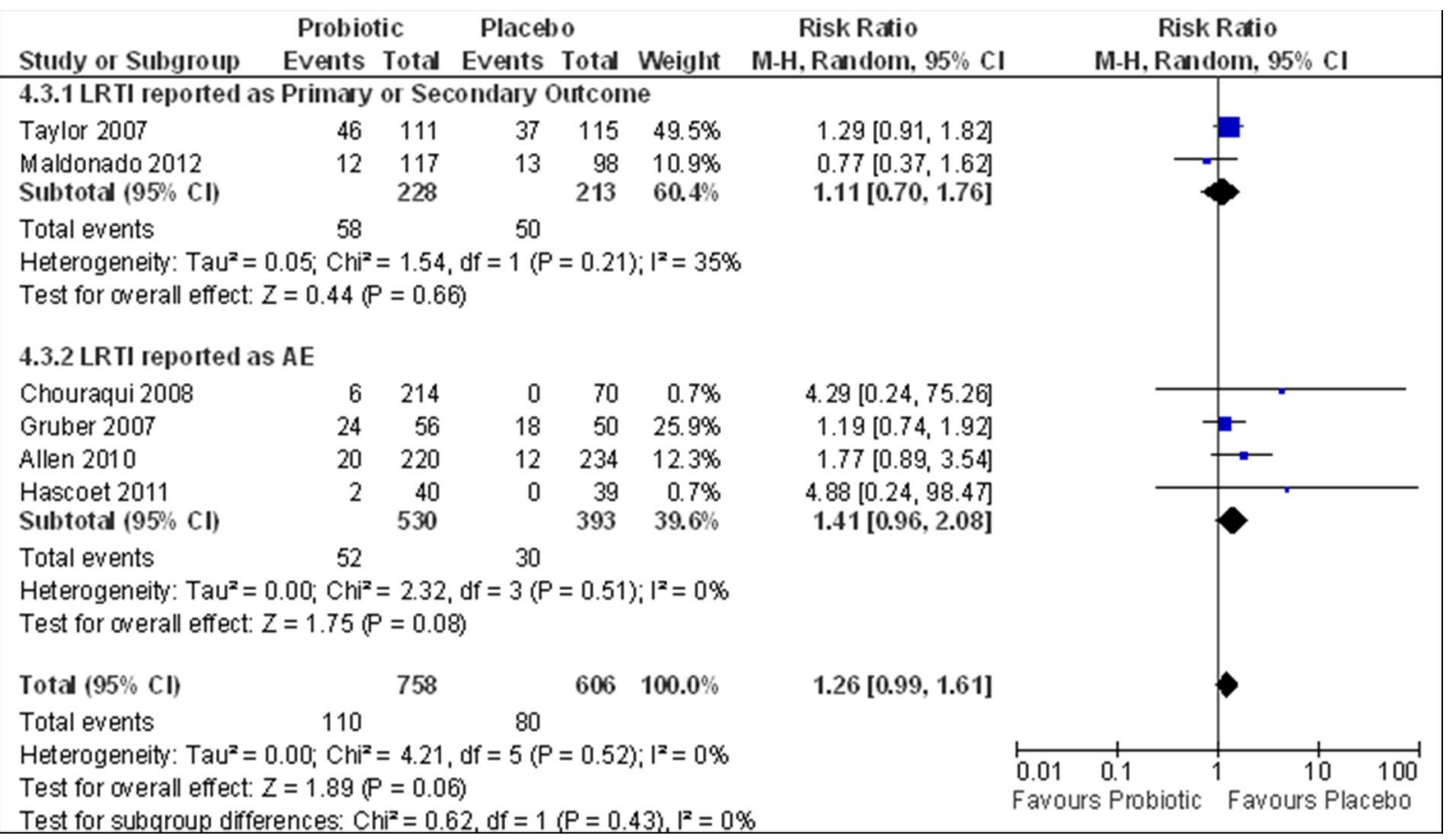

Fig 4 Probiotic supplementation during pregnancy or infancy and lower respiratory tract infection in children. The longest available follow-up data (intention to treat) were extracted from each contributing trial. Trials are sorted in order of decreasing duration of follow-up, and subgrouped according to whether the incidence of lower respiratory tract infection was systematically reported as a primary or secondary outcome, or as an adverse event. AE=adverse event; $d f=d$ egrees of freedom; LRTI=lower respiratory tract infection; $\mathrm{M}-\mathrm{H}=$ Mantel-Haenszel 